\title{
RANCANG BANGUN PAKAN IKAN OTOMATIS TENAGA SURYA BERBASIS PROGRAMMABLE LOGIC CONTROLLER
}

\author{
Derman $^{1}$, Budiani Destyningtias ${ }^{2}$, Arif Suprasetyo ${ }^{3}$ \\ 1,2,3 Jurusan Teknik Elektro Fakultas Teknik Universitas Semarang \\ Jl. Soekarno-Hatta, Tlogosari Semarang. \\ Email: derman.mte@gmail.com; budiani_desty@yahoo.co.id; arif.suprasetyo@gmail.com
}

\begin{abstract}
RINGKASAN
Pemberian pakan merupakan salah satu hal penting untuk usaha budidaya ikan. Saat ini pemberian pakan umumnya masih tergantung pada sumber daya manusia yang bersifat manual. Oleh karena itu dirancang alat untuk memberi pakan ikan yang dapat bekerja secara otomatis berdasarkan waktu atau jadwal pemberian pakan dan takaran pakan. Pakan ikan otomatis ini menggunakan PLC (Programmable Logic Controller) yang merupakan pengontrol utama, Inverter sebagai pengubah tegangan DC ke AC dari panel surya ke charge controller, Panel surya sebagai pembangkit listrik yang diperoleh dari sinar matahari yang dilengkapi dengan charge controller dan aki sebagai penyimpan dan penyalur tegangan. Hasil Penelitian menunjukkan bahwa alat penjadwalan pakan ikan otomatis tenaga surya menggunakan PLC telah berfungsi dengan baik. Alat tersebut bekerja berdasarkan sistem penjadwalan yang telah di setting melalui software cx-one programmer ke PLC. Alat akan bekerja sesuai jadwal yang telah diatur yaitu jam 7 pagi dan jam 4 sore serta kapasitas pakan yang keluar sudah terencana yaitu 1 Menit 30 detik. Pada saat pengujian nilai rata-rata tegangan solar cell tanpa beban adalah 38,69 Vdc, sedangkan pada posisi berbeban didapatkan 36,92 Vdc, nilai rata-rata arus solar cell tanpa beban adalah 1,80 A, sedangkan pada posisi berbeban didapatkan 1,56 A. Nilai rata-rata daya solar cell tanpa beban adalah 70,02 W, sedangkan pada posisi berbeban didapatkan $48,74 \mathrm{~W}$ dan juga pada inverter menghasilkan daya keluaran rata-rata adalah 201,43 W.
\end{abstract}

Kata Kunci : Pakan Ikan,Otomatis, Tenaga Surya, Programmable Logic Controller

\section{PENDAHULUAN}

\subsection{Latar Belakang}

Perkembangan teknologi otomasi salah satunya dengan memanfaatkan PLC (Programmable Logic Controller) sebagai alat pengendali terprogram semakin meningkat dengan pesat saat ini. Implementasi dapat kita temukan diberbagai bidang seperti Industri, Transportasi, Pertanian dan juga Perikanan. Pada bidang perikanan diharapkan ada sebuah alat yang dapat mengatasi masalah pemberian pakan secara manual menjadi otomatis, seperti bidang yang lain yang sudah banyak diterapkan dengan memanfaatkan PLC. Hal itu dilakukan karena sistem yang PLC dapat melakukan kendali secara rutin, terus-menerus, dan tidak terbatas pada waktu.

Pada budidaya ikan, pakan sangat dibutuhkan untuk perkembangan ikan. Ketersediaan pakan akan berpengaruh terhadap pertumbuhan dan kelangsungan hidup ikan yang dibudidayakan. Sehingga kebutuhan pakan juga harus sesuai dengan porsi yang dibutuhkan ikan. Selain itu jadwal pemberian pakan juga harus diatur agar ikan dapat tumbuh dan berkembang secara optimal.

Pada pembudidaya ikan di Tambak Lorok Tanjung Mas Semarang. Pemberian pakan ikan masih dilakukan secara manual yaitu dengan menaburkan pakan pada lokasi tambak. Oleh sebab itu penjadwalan pakan perlu dilakukan agar teraturnya pemberian pakan pada ikan dan membuat pertumbuhan ikan lebih cepat.
Penelitian ini bertujuan merancang bangun sebuah alat yang dapat mengatasi masalah pemberian pakan ikan yang masih menggunakan cara manual menjadi otomatis, memiliki sistem penjadwalan yang terprogram dan bermanfaat bagi banyak orang khususnya pembudidaya ikan. Alat yang peneliti rancang merupakan alat yang terprogram melalui PLC yang dilengkapi dengan panel surya. PLC dapat diprogram, dikontrol, dan dioperasikan oleh operator. Sedangkan panel surya dapat secara langsung (direct) untuk mentransfer radiasi matahari atau energi cahaya menjadi energi listrik. Dengan dukungan charge controller dan aki sebagai tenaga utama dalam menghidupkan PLC serta motor DC yang difungsikan untuk penyebaran pakan ikan. Sehingga dengan prototype alat ini dapat memberikan solusi cara pemberian pakan dengan efektif bagi para pembudidaya ikan dalam proses pemberian pakan ikan.

\section{Landasan Teori \\ 2.1 Rancang Bangun}

Rancang merupakan serangkaian prosedur untuk menerjemahkan hasil analisa dari sebuah sistem ke dalam bahasa pemrograman untuk mendeskripsikan dengan detail bagaimana komponen-komponen sistem diimplementasikan (Pressman, 2002). Perancangan adalah kegiatan yang memiliki tujuan untuk mendesain sistem baru yang dapat menyelesaikan masalah-masalah yang dihadapi perusahaan yang diperoleh dari pemilihan alternatif sistem yang terbaik (Ladjamudin, 2005). 
Pembangunan atau bangun sistem adalah kegiatan menciptakan sistem baru maupun mengganti atau memperbaiki sistem yang telah ada baik secara keseluruhan maupun sebagian (Pressman, 2002). Bangun sistem adalah membangun sistem informasi dan komponen yang didasarkan pada spesifikasi desain (Whitten et al, 2004). Jadi dapat disimpulkan bahwa Rancang Bangun adalah penggambaran perencanaan, dan pembuatan sketsa atau pengaturan dari beberapa elemen yang terpisah kedalam suatu kesatuan yang utuh dan berfungsi. Dengan demikian pengertian rancang bangun merupakan kegiatan menerjemahkan hasil analisa ke dalam bentuk paket perangkat lunak kemudian menciptakan sistem tersebut atau memperbaiki sistem yang sudah ada.

\subsection{Penjadwalan}

Penjadwalan adalah kegiatan pengalokasian sumber-sumber atau mesin-mesin yang ada untuk menjalankan sekumpulan tugas dalam jangka waktu tertentu (Baker, 1974). Penjadwalan produksi adalah suatu kegiatan memasukkan sejumlah produk yang telah direncanakan ke dalam proses pengerjaannya (John E Biegel, 1992). Penjadwalan adalah proses pengurutan pembuatan produk secara menyeluruh pada beberapa mesin (Conway,et,al, 1967). Penjadwalan juga didefinisikan sebagai rencana pengaturan urutan kerja serta pengalokasian sumber, baik waktu maupun fasilitas untuk setiap operasi yang harus diselesaikan (Vollman, 1998). Dari beberapa definisi yang telah disebutkan maka dapat ditarik satu definisi "Penjadwalan adalah suatu kegiatan perancangan berupa pengalokasian sumber daya baik mesin maupun tenaga kerja untuk menjalankan sekumpulan tugas sesuai prosesnya dalam jangka waktu tertentu".

Unsur-unsur vital didalam model-model penjadwalan adalah sumber-sumber dan tugastugas.Sumber-sumber biasanya dikenal dengan mesin-mesin sedangkan tugas-tugas dikenal dengan job atau pekerjaan. Menurut L. Bethel dalam bukunya "Industrial Organization and Management" memberikan definisi penjadwalan atau scheduling sebagai berikut :Penjadwalan produksi merupakan proses penentuan pekerjaan yang akan dilakukan. Penjadwalan (scheduling) adalah suatu tahapan dari pengawasan produksi yang menetapkan pekerjaan dalam urut-urutan yang sesuai dengan prioritasnya dan kemudian dilengkapi pelaksanaan rencana tersebut pada waktu yang tepat dengan urutan yang benar, sehingga berhubungan dengan kapan suatu pekerjaan akan dilaksanakan pada suatu bagian produksi.

\subsection{Tujuan Penjadwalan}

1. Menurut Baker (1974), tujuan penjadawalan umumnya adalah sebagai berikut: a. Meningkatkan produktifitas mesin, yaitu dengan mengurangi waktu mesin menganggur.

b. Mengurangi persediaan barang setengah jadi dengan jalan mengurangi jumlah ratarata pekerjaan yang menunggu dalam antrian suatu mesin karena mesin tersebut sibuk.

c. Mengurangi keterlambatan suatu pekerjaan. Setiap pekerjaan mempunyai batas waktu (due date) penyelesaian, jika pekerjaan tersebut diselesaikan melewati batas waktu yang ditentukan maka pekerjaan tersebut dinyatakan terlambat. Dengan metoda penjadwalan maka keterlambatan ini dapat dikurangi, baik waktu maupun frekuensi.

2. Menurut Narasimhan (1985), penjadwalan yang baik seharusnya simpel, mudah dimengerti dan dapat dilaksanakan oleh pihak manajemen dan oleh siapapun yang menggunakannya. Aturanaturan penjadwalan seharusnya cukup kuat tetapi mempunyai tujuan yang realistis sehingga cukup flexible untuk memecahkan masalah yang tidak terprediksi sebelumnya dan membolehkan satu perencanaan ulang.

3. Bedworth (1987) mengidentifikasikan beberapa tujuan dari aktivitas penjadwalan, adalah sebagai berikut:

a. Meningkatkan penggunaan sumber daya atau mengurangi waktu tunggunya, sehingga total waktu proses dapat berkurang dan produktivitas dapat meningkat.

b. Mengurangi persediaan barang setengah jadi atau mengurangi sejumlah pekerjaan menunggu dalam antrian ketika sumber daya yang ada masih mengerjakan tugas yang lain. Teori Baker mengatakan, jika aliran kerja suatu jadwal konstan, maka antrian yang mengurangi rata-rata waktu alir akan mengurangi rata-rata persediaan barang setengah jadi.

c. Mengurangi beberapa kelambatan pada pekerjaan yang mempunyai batas waktu penyelesaian sehingga akan meminimalisasi penalty cost (biaya kelambatan).

d. Membantu pengambilan keputusan mengenai perencanaan kapasitas pabrik dan jenis kapasitas yang dibutuhkan sehingga penambahan biaya yang mahal dapat dihindarkan.

\subsection{Pakan Ikan}

Pakan adalah makanan/asupan yang diberikan kepada hewan ternak (peliharaan). Istilah ini diadopsi dari bahasa Jawa. Pakan merupakan sumber energi dan materi bagi pertumbuhan dan dan 
kehidupan makhluk hidup. Zat yang terpenting dalam pakan adalah protein. Pakan merupakan faktor tumbuh terpenting karena merupakan sumber energi yang menjaga pertumbuhan, serta perkembangbiakan. Nutrisi yang terkandung dalam pakan harus benar-benar terkontrol dan memenuhi kebutuhan ikan tersebut. Kualitas dari pakan ditentukan oleh kandungan yang lengkap mencakup protein, lemak, karbohidrat, vitamin dan mineral. Pakan merupakan sumber energi dan materi bagi kehidupan ikan. Ketersediaan pakan berpengaruh besar terhadap pertumbuhan dan kelangsungan hidup ikan. Jumlah pakan yang dibutuhkan oleh ikan setiap harinya berhubungan erat dengan ukuran berat dan umurnya. Tetapi persentase jumlah pakan yang dibutuhkan semakin berkurang dengan bertambahnya ukuran dan umur ikan. Pakan ikan adalah campuran dari berbagai bahan pangan (biasa disebut bahan mentah), baik nabati maupun hewani yang diolah sedemikian rupa sehingga mudah dimakan dan dicerna sekaligus merupakan sumber nutrisi bagi ikan yang dapat menghasilkan energi untuk aktivitas hidup. Kelebihan energi yang dihasilkan akan disimpan dalam bentuk daging yang dipergunakan untuk pertumbuhan (Djarijah, 1996).

\subsection{Panel Surya}

Berdasarkan catatan sejarah, teknologi panel surya bahkan sudah ada di abad ke-18, tepatnya pada tahun 1839 seorang ahli fisika asal Perancis bernama Alexandre Edmund Becquerel pertama kali mencetuskan teknologi panel surya. Awalnya teknologi panel surya pertama kali dicetuskan oleh beliau melalui percobaan penyinaran dua elektroda menggunakan berbagai spektrum cahaya yang menghasilkan efek Photovoltaic. Photovoltaic $($ Photo $=$ cahaya dan voltaic $=$ tegangan listrik $)$ merupakan proses pembentukan energi listrik dari energi cahaya. Namun pada saat itu, jumlah energi listrik yang dihasilkan terlalu sedikit dan mudah habis.

Kemudian di tahun 1876, seorang guru bernama William Grylls Adam dan muridnya Richards Evans Day memperkuat penelitian Alexandre Edmund Becquerel yang mengemukakan bahwa di dunia ini terdapat benda material padat, yakni selenium yang dapat menghasilkan energi listrik apabila selenium terkena sinar tertentu. Meski hanya menghasilkan energi listrik dalam jumlah sedikit namun percobaan ini sekaligus membuktikan bahwa energi listrik dapat dihasilkan dari energi cahaya.

Pada tahun 1904, Albert Einstein pernah meneliti mengenai solar sell dan beliau menamakan percobaan tersebut dengan nama Efek Fotolistrik. Barulah di tahun 1941, peneliti bernama Russel Ohl berhasil mengembangkan teknologi panel surya sekaligus mematenkan produknya tersebut. Beliau dikenal sebagai orang pertama yang menemukan teknologi solar cell (panel surya) dan penggunaan panel surya buatannya masih digunakan sampai sekarang. Dalam pembuatan panel surya, beliau membutuhkan silicon. Sebuah panel surya dapat menghasilkan listrik karena bahan semikonduktor di dalamnya seperti silikon. Ketika silikon berkontak langsung dengan cahaya, maka dapat menimbulkan reaksi yang nantinya menghasilkan energi listrik.

\subsection{Programmable Logic Control (PLC)}

Programmable Logic Control merupakan suatu bentuk khusus pengontrol berbasis microprocessor yang memanfaatkan memori yang dapat diprogram untuk menyimpan instruksi - instruksi dan untuk mengimplementasikan fungsi - fungsi semisal logika, sequencing, pewaktuan (timing), pencacahan (counting) dan aritmatika guna mengontrol mesinmesin dan proses-proses serta dirancang untuk dioperasikan oleh para insinyur yang hanya memiliki sedikit pengetahuan mengenai komputer dan bahasa pemrograman (Wiliam Bolton, 2004).

Sebagian besar industri telah menerapkan sistem otomatis dalam proses produksi. Pada umumnya sistem otomatis yang diterapkan terdiri atas dua metode yaitu otomatisasi berbasis kontrol relay dan otomatisasi berbasis Programmable Logic Control (PLC). Otomatisasi berbasis relay banyak digunakan pada mesinmesin yang memiliki urutanurutan (sekuens) yang sederhana, sedangkan otomatisasi PLC dapat memiliki sekuens yang lebih kompleks dari relay. Otomatisasi berbasis PLC dapat diintegrasikan dengan sistem monitoring. Sistem monitoring berbasis PLC adalah suatu sistem yang berguna untuk mengontrol proses suatu kerja tertentu., dimana parameter atau inputan data diambil dan diolah oleh Personal Computer (PC) dan melalui sebuah program tertentu (Wiliam Bolton, 2006).

\section{METODOLOGI PENELITIAN}

\subsection{Rancangan Penelitian}

Penulisan tugas akhir ini, yang digunakan adalah metode rancang bangun. Rancang bangun tersebut adalah Rancang Bangun Alat Penjadwalan Pakan Ikan Otomatis Tenaga Surya Menggunakan PLC. Dengan daya dari hasil sendiri tanpa harus mengambil daya dari PLN. Sehingga alat dapat bekerja otomatis dalam proses pakan ikan dengan waktu yang telah diatur melalui program cx one programmer melalui PLC. 


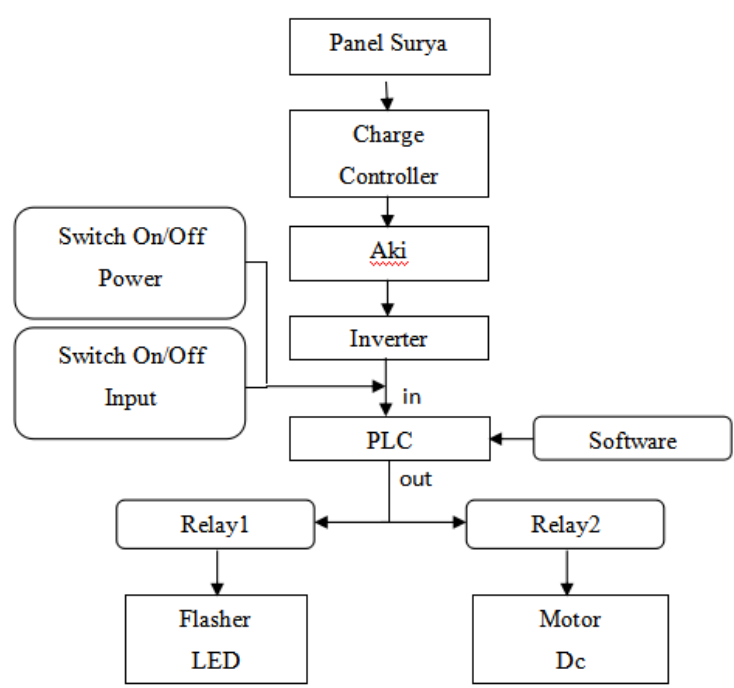

Gambar 3.1. Blok Diagram Alat

\subsection{Alat dan Bahan Penelitian}

\section{Alat Penelitian}

Sebagai penunjang pelaksanaan pembuatan penelitian ini digunakan beberapa alat dalam menunjang kebutuhan sebuah penelitian seperti : Bor Listrik, Tang Kombinasi, Cutter, Multimeter, Obeng, Gergaji, Kunci Pas, Gunting

\section{Bahan Penelitian}

Bahan yang dibutuhkan dalam pembuatan rancang bangun alat penjadwalan pakan ikan otomatis tenaga surya menggunakan plc yaitu :

a. SoftwarE : CX-ONE Programmer

b. Hardware : PLC ( Programmable Logic Controller ), Photovoltaic, Aki, Inverter, Pipa Paralon, Motor DC, Kabel, Solar Charge Controller, Besi Siku, Relay, Kotak Panel, Terminal, Lem.

\subsection{Tempat dan Waktu Penelitian}

Rancang bangun alat penjadwalan otomatis tenaga surya menggunakan PLC ini dilaksanakan di Laboratorium Teknik Elektro Universitas Semarang, selama kurun waktu kurang lebih 6 bulan. Dan pengujian alat dilakukan di wilayah Tambak Lorok Tanjung Mas Semarang.

\subsection{Prosedur Penelitian}

Pada penelitian dan pembuatan Alat Pakan Ikan Otomatis Tenaga Surya Menggunakan PLC ini terbagi menjadi lima tahapan. Lima tahapan tersebut adalah tahap persiapan, tahap perancangan, tahap pembuatan, tahap pengujian alat, lalu tahap analisis data. Pada analisis data jika diperoleh data hasil yang tidak sesuai maka akan dilakukan pengujian ulang hingga sesuai dan siap pakai. Diagram alur prosedur penelitian secara lengkap dapat disajikan pada Gambar 2.2.

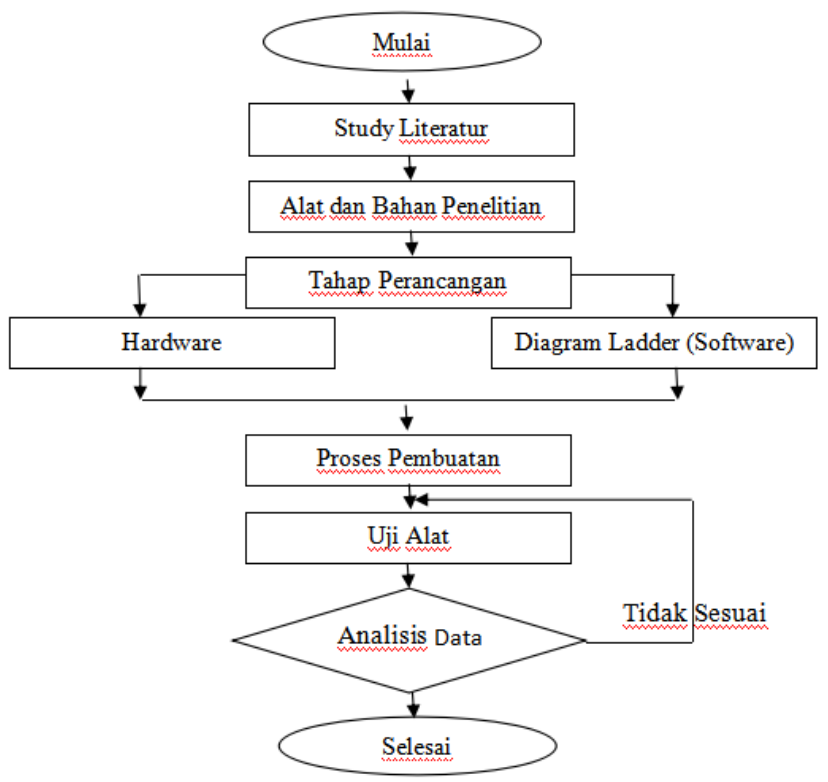

Gambar 3.2. Flowchart Prosedur Penelitian

Pada tahap ini proses yang dilakukan adalah pencarian informasi dengan studi pustaka pada beberapa literature, jurnal ilmiah dan tugas akhir yang berhubungan dengan alat penjadwalan pakan ikan otomatis serta mempersiapkan komponen apa saja yang akan digunakan. Selain itu juga mempersiapkan pula alat-alat yang dibutuhkan untuk menunjang proses penelitian dan pembuatan rancang bangun alat penjadwalan pakan ikan otomatis tenaga surya menggunakan plc. Juga dipersiapkan software CX-One Programmer untuk mengolah data sehingga alat dapat bekerja sesuai perintah.

\subsection{Tahap Perancangan}

Pada tahap perancangan ini terbagi menjadi perancangan perangkat keras (hardware) dan perancangan perangkat lunak (software).

\subsection{Perancangan Perangkat Keras (Hardware)}

Dalam perancangan hardware diperlukan beberapa komponen yang menyusun menjadi sebuah alat pakan ikan otomatis

\subsection{Perancangan Perangkat Lunak ( Software )}

Software yang digunakan pada penelitian ini adalah Cx-One Programmer. Setelah data dikirim ke PLC selanjutnya akan diolah oleh PLC untuk menjalankan komponen lainnya dan bekerja sesuai konsep. 


\section{HASIL DAN PEMBAHASAN \\ 4.1. Pengukuran Tegangan, Arus dan Daya Panel Surya}

Tabel 4.1. Hasil Pengukuran Tegangan, Arus dan Daya Panel Surya

\begin{tabular}{|c|c|c|c|c|c|c|}
\hline \multirow{3}{*}{ Waktu } & \multicolumn{2}{|c|}{ Tanpa Beban } & \multirow{2}{*}{$\frac{\text { Daya }}{\text { Watt }}$} & \multicolumn{2}{|c|}{ Dengan Beban } & \multirow{2}{*}{$\begin{array}{c}\text { Daya } \\
\text { Watt }\end{array}$} \\
\hline & Volt & Ampere & & Volt & Ampere & \\
\hline & Vdc & Idc & $\mathrm{P}$ & Vdc & Idc & $\mathrm{P}$ \\
\hline $08: 40-08: 55$ & 37,69 & 1,65 & 62,18 & 35,75 & 1,55 & 55,41 \\
\hline 08:55 - 09:10 & 37,64 & 1,34 & 50,43 & 35,77 & 1,21 & 43,28 \\
\hline $09: 10-09: 25$ & 38,25 & 1,83 & 69,99 & 36,09 & 1,54 & 55,57 \\
\hline $09: 25-09: 40$ & 38,62 & 2,10 & 81,10 & 36,56 & 1,52 & 55,57 \\
\hline 09:40 - 09:55 & 37,75 & 1,52 & 57,38 & 36,58 & 1,35 & 49,38 \\
\hline $09: 55-10: 10$ & 39,11 & 2,06 & 80,56 & 37,01 & 1,79 & 66,24 \\
\hline $10: 10-10: 25$ & 40,21 & 1,73 & 69,56 & 38,87 & 1,66 & 64,52 \\
\hline $10: 25-10: 40$ & 40,28 & 2,21 & 89,01 & 38,79 & 1,89 & 73.31 \\
\hline
\end{tabular}

Tabel 4.2. Perhitungan Daya Panel Surya

\begin{tabular}{|c|c|c|}
\hline Waktu & Tanpa Beban & Berbeban \\
\hline \multirow{3}{*}{$08: 40-08: 55$} & $\mathrm{P}=\mathrm{Vdc} \times \mathrm{Idc}$ & $\mathrm{P}=\mathrm{Vdc} \times \mathrm{Idc}$ \\
\hline & $=37,69 \mathrm{~V} \times 1,65 \mathrm{~A}$ & $=35,75 \mathrm{~V} \times 1,55 \mathrm{~A}$ \\
\hline & $=62,18 \mathrm{~W}$ & $=55,41 \mathrm{~W}$ \\
\hline \multirow{3}{*}{$08: 55-09: 10$} & $\mathrm{P}=\mathrm{Vdc} \times \mathrm{Idc}$ & $\mathrm{P}=\mathrm{Vdc} \times \mathrm{Idc}$ \\
\hline & $=37,64 \mathrm{~V} \times 1,34 \mathrm{~A}$ & $=35,77 \mathrm{~V} \times 1,21 \mathrm{~A}$ \\
\hline & $=50,43 \mathrm{~W}$ & $=43,28 \mathrm{~W}$ \\
\hline \multirow{3}{*}{$09: 10-09: 25$} & $\mathrm{P}=\mathrm{Vdc} \times \mathrm{Idc}$ & $\mathrm{P}=\mathrm{Vdc} \times \mathrm{Idc}$ \\
\hline & $=38,25 \mathrm{~V} \times 1,83 \mathrm{~A}$ & $=36,09 \mathrm{~V} \times 1,54 \mathrm{~A}$ \\
\hline & $=69,99 \mathrm{~W}$ & $=55,57 \mathrm{~W}$ \\
\hline \multirow{3}{*}{$09: 25-09: 40$} & $\mathrm{P}=\mathrm{Vdc} \times \mathrm{Idc}$ & $\mathrm{P}=\mathrm{Vdc} \times \mathrm{Idc}$ \\
\hline & $=38,62 \mathrm{~V} \times 2,10 \mathrm{~A}$ & $=36,56 \mathrm{~V} \times 1,52 \mathrm{~A}$ \\
\hline & $=81,10 \mathrm{~W}$ & $=55,57 \mathrm{~W}$ \\
\hline \multirow{3}{*}{$09: 40-09: 55$} & $\mathrm{P}=\mathrm{Vdc} \times \mathrm{Idc}$ & $\mathrm{P}=\mathrm{Vdc} \times \mathrm{Idc}$ \\
\hline & $=37,75 \mathrm{~V} \times 1,52 \mathrm{~A}$ & $=36,58 \mathrm{~V} \times 1,35 \mathrm{~A}$ \\
\hline & $=57,38 \mathrm{~W}$ & $=49,38 \mathrm{~W}$ \\
\hline \multirow{3}{*}{$09: 55-10: 10$} & $\mathrm{P}=\mathrm{Vdc} \times \mathrm{Idc}$ & $\mathrm{P}=\mathrm{Vdc} \times \mathrm{Idc}$ \\
\hline & $=39,11 \mathrm{~V} \times 2,06 \mathrm{~A}$ & $=37,01 \mathrm{~V} \times 1,79 \mathrm{~A}$ \\
\hline & $=80,56 \mathrm{~W}$ & $=66,24 \mathrm{~W}$ \\
\hline \multirow{3}{*}{$10: 10-10: 25$} & $\mathrm{P}=\mathrm{Vdc} \times \mathrm{Idc}$ & $\mathrm{P}=\mathrm{Vdc} \times \mathrm{Idc}$ \\
\hline & $=40,21 \mathrm{~V} \times 1,73 \mathrm{~A}$ & $=38,87 \mathrm{~V} \times 1,66 \mathrm{~A}$ \\
\hline & $=69,56 \mathrm{~W}$ & $=64,52 \mathrm{~W}$ \\
\hline \multirow{3}{*}{$10: 25-10: 40$} & $\mathrm{P}=\mathrm{Vdc} \times \mathrm{Idc}$ & $\mathrm{P}=\mathrm{Vdc} \times \mathrm{Idc}$ \\
\hline & $=40,28 \mathrm{~V} \times 2,21 \mathrm{~A}$ & $=38,79 \mathrm{~V} \times 1,89 \mathrm{~A}$ \\
\hline & $=89,01 \mathrm{~W}$ & $=73.31 \mathrm{~W}$ \\
\hline
\end{tabular}




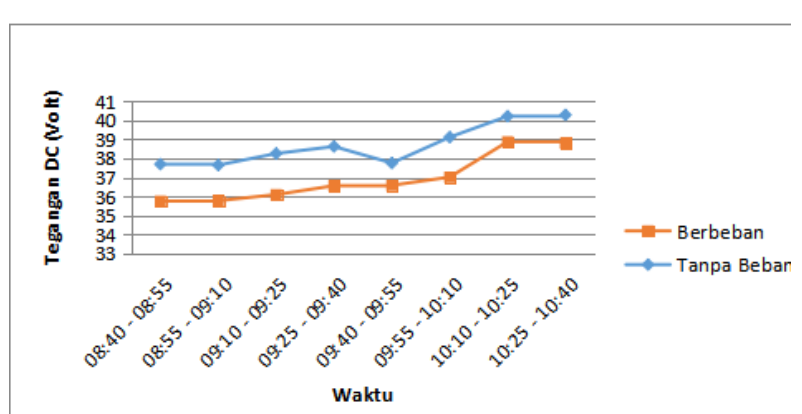

Gambar 4.3. Grafik Tegangan Solar Cell

Dari grafik diatas dan tabel 4.1. di atas dapat dilihat bahwa rata-rata tegangan solar cell tanpa beban adalah 38,69 Vdc, sedangkan pada posisi berbeban didapatkan 36,92 Vdc.

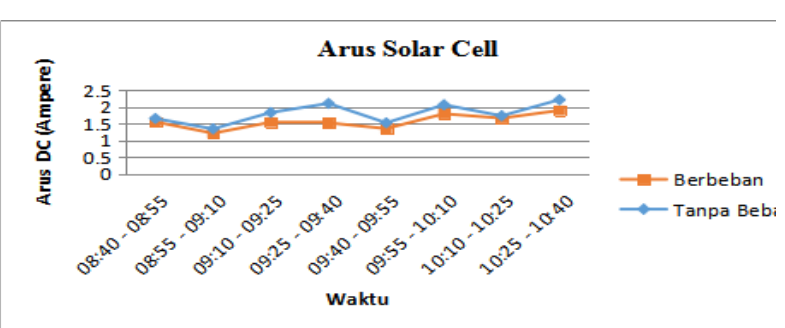

Gambar 4.4. Grafik Arus Solar Cell

Dari grafik diatas dan tabel 4.1. di atas dapat dilihat bahwa rata-rata arus solar cell tanpa beban adalah 1,80 A, sedangkan pada posisi berbeban didapatkan $1,56 \mathrm{~A}$.

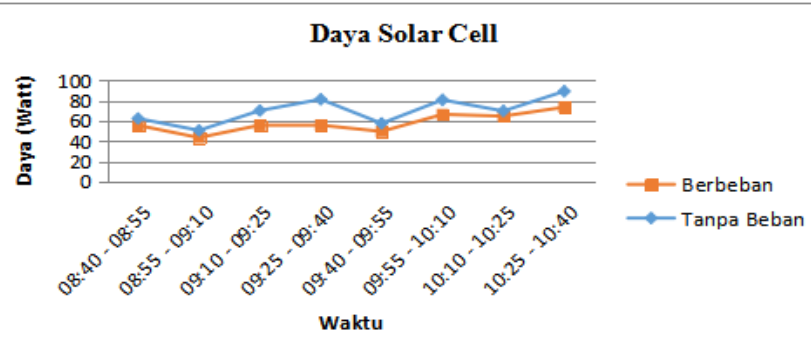

Gambar 4.5. Grafik Arus Solar Cell

Dari grafik diatas dan tabel 3.1. di atas dapat dilihat bahwa rata-rata daya solar cell tanpa beban adalah $70,02 \mathrm{~W}$, sedangkan pada posisi berbeban didapatkan 48,74 W.

Tabel 4.6. Pengukuran Tegangan, Arus dan Daya Inverter

\begin{tabular}{|c|c|c|c|}
\hline \multirow{2}{*}{ Waktu } & \multicolumn{3}{|c|}{ Output } \\
\cline { 2 - 4 } & Tegangan & Arus & Daya \\
\cline { 2 - 4 } & $\operatorname{Vac}(\mathrm{V})$ & $\mathrm{Iac}(\mathrm{A})$ & $\mathrm{P}(\mathrm{W})$ \\
\hline $08: 40-08: 55$ & 220,2 & 0,99 & 218 \\
\hline $08: 55-09: 10$ & 219,7 & 0,96 & 210,91 \\
\hline $09: 10-09: 25$ & 220,1 & 0,93 & 204,69 \\
\hline $09: 25-09: 40$ & 221,9 & 0,98 & 217,46 \\
\hline $09: 40-09: 55$ & 220,8 & 0,9 & 198,72 \\
\hline $09: 55-10: 10$ & 220,3 & 0,87 & 191,66 \\
\hline $10: 10-10: 25$ & 220,3 & 0,85 & 187,26 \\
\hline $10: 25-10: 40$ & 220,2 & 0,83 & 182,77 \\
\hline
\end{tabular}

Dari tabel 4.6. di atas dapat dilihat bahwa nilai ratarata daya inverter adalah $201,43 \mathrm{~W}$

Tabel 4.7. Perhitungan Daya Inverter

\begin{tabular}{|c|c|c|c|}
\hline Waktu & Daya (Watt) & Waktu & Daya (Watt) \\
\hline \multirow{3}{*}{ 08:40 - 08:55 } & $\mathrm{P}=\mathrm{Vac} \times \mathrm{Iac}$ & \multirow{3}{*}{$09: 40-09: 55$} & $\mathrm{P}=\mathrm{Vac} \times \mathrm{Iac}$ \\
\hline & $=220,2 \mathrm{~V} \times 0,99 \mathrm{~A}$ & & $=220,8 \mathrm{~V} \times 0,9 \mathrm{~A}$ \\
\hline & $=218 \mathrm{~W}$ & & $=198,72 \mathrm{~W}$ \\
\hline \multirow{3}{*}{ 08:55 - 09:10 } & $\mathrm{P}=\mathrm{Vac} \times \mathrm{Iac}$ & \multirow{3}{*}{$09: 55-10: 10$} & $\mathrm{P}=\mathrm{Vac} \times \mathrm{Iac}$ \\
\hline & $=219,7 \mathrm{~V} \times 0,96 \mathrm{~A}$ & & $=220,3 \mathrm{~V} \times 0,87 \mathrm{~A}$ \\
\hline & $=210,91 \mathrm{~W}$ & & $=191,66 \mathrm{~W}$ \\
\hline \multirow{3}{*}{$09: 10-09: 25$} & $\mathrm{P}=\mathrm{Vdc} \times \mathrm{Idc}$ & \multirow{3}{*}{$10: 10-10: 25$} & $\mathrm{P}=\mathrm{Vac} \times \mathrm{Iac}$ \\
\hline & $=220,1 \mathrm{~V} \times 0,93 \mathrm{~A}$ & & $=220,3 \mathrm{~V} \times 0,85 \mathrm{~A}$ \\
\hline & $=204,69 \mathrm{~W}$ & & $=187,26 \mathrm{~W}$ \\
\hline \multirow{3}{*}{$09: 25-09: 40$} & $\mathrm{P}=\mathrm{Vac} \times \mathrm{Iac}$ & \multirow{3}{*}{$10: 25-10: 40$} & $\mathrm{P}=\mathrm{Vac} \times \mathrm{Iac}$ \\
\hline & $=221,9 \mathrm{~V} \times 0,98 \mathrm{~A}$ & & $=220,2 \mathrm{~V} x 0,83 \mathrm{~A}$ \\
\hline & $=217,46 \mathrm{~W}$ & & $=182,77 \mathrm{~W}$ \\
\hline
\end{tabular}




\subsection{Penjadwalan Pakan Ikan}

Penjadwalan Pakan Ikan Otomatis ini bekerja dengan ketentuan sebagai berikut:

a. Jadwal ON pertama pada pagi hari disetting 1 Menit 30 detik waktu nyala motor dan flasher di jam 07.00.00 dan akan off otomatis setelah waktu nyala selesai yaitu jam 07.01.30

b. Jadwal ON kedua pada sore hari disetting 1 Menit 30 detik waktu nyala motor dan flasher di jam 16.00.00 dan akan off otomatis setelah waktu nyala selesai yaitu 16.01.30.

Tabel 4.8. Penjadwalan Pakan Ikan

\begin{tabular}{|c|c|c|c|c|}
\hline $\begin{array}{c}\text { Waktu } \\
\text { (Jam, Menit, Detik) }\end{array}$ & Motor & Flasher & $\begin{array}{c}\text { Penyebaran } \\
\text { Pakan }\end{array}$ & $\begin{array}{c}\text { Jumlah Pakan yang } \\
\text { Keluar }\end{array}$ \\
\hline 07.00 .00 & ON & ON & Aktif & $1,5 \mathrm{Kg}$ \\
\hline 07.01 .30 & OFF & OFF & Nonaktif & \multirow{2}{*}{$1,5 \mathrm{Kg}$} \\
\hline \hline 16.00 .00 & ON & ON & Aktif & \\
\hline 16.01 .30 & OFF & OFF & Nonaktif & \\
\hline
\end{tabular}

\section{PENUTUP}

\subsection{Kesimpulan}

1. Perancangan alat penjadwalan pakan ikan otomatis tenaga surya menggunakan PLC telah berfungsi dengan baik. Alat tersebut bekerja berdasarkan sistem penjadwalan yang telah di setting melalui software cx-one programmer ke PLC. Alat akan bekerja sesuai jadwal yang telah diatur yaitu jam 7 pagi dan jam 4 sore serta kapasitas pakan yang keluar sudah terencana yaitu 1 Menit 30 detik untuk $1,5 \mathrm{Kg}$.

2. Pada saat pengujian rata-rata tegangan solar cell tanpa beban adalah 38,69 Vdc, sedangkan pada posisi berbeban didapatkan $36,92 \mathrm{Vdc}$, rata-rata arus solar cell tanpa beban adalah 1,80 A, sedangkan pada posisi berbeban didapatkan 1,56 A.

3. Nilai rata-rata daya solar cell tanpa beban adalah 70,02 W, sedangkan pada posisi berbeban didapatkan $48,74 \mathrm{~W}$ dan juga pada inverter menghasilkan daya keluaran rata-rata adalah $201,43 \mathrm{~W}$.

\subsection{Saran}

Alat Penjadwalan pakan ikan otomatis tenaga surya menggunakan PLC masih belum sempuna dan masih banyak yang perlu dikembangkan, sehingga para pembudidaya ikan tambak dapat mengembangkan alat ini dan menyesuaikan alat dengan tempat agar dapat membantu mempermudah dalam pemberian pakan

\section{DAFTAR PUSTAKA}

Al-Bahra bin Ladjamudin. (2005). Analisis dan Desain Sistem Informasi. Yogyakarta : Graha Ilmu.

Anonim. (2010). Technical Application Papers No. 10 Photovoltaic Platns. Italy: ABB SACE

Bolton, Wiliam. (2004). Programmable Logic Controller (PLC). Sebuah pengantar / W Bolton. alih bahasa irzam Harmein. editor H.M. Wibi Hardani. Jakarta : Erlangga

Budiyanto, M., A. Wijaya, Pengenalan Dasar-dasar PLC (Programmable Logic Controller), Gava Media, Yogyakarta

CX-Programmer User Manual Version 9.5 Djarijah A S. 1996. Pakan Ikan Alami. Yogyakarta : Kanisius.

Nulhakim, Lukman. (2014). Alat Pemberi Makan Ikan di Akuarium Otomatis Berbasis Mikrokontroller Atmega16 Proyek Akhir. Jurusan Teknik Elektro Fakultas Teknik Universitas Negeri Yogyakarta.

OMRON. 2009. SYSMAC CP1L Introduction Manual

Pasila,Felix., Stephanus A., Nelson Kusuma R. (2004). Sistem Automasi Proses Produksi Minuman dengan Sistem SCADA Menggunakan PLC. Paper. Fakultas Teknologi Industri Jurusan Teknik Elektro UK Petra, Surabaya.

Rosyadi, Nasrul Haq. 2016. Anialisis Potensi Pembangkit Listrik Tenaga Hibrida Energi Angin dan Energi Surya Dalam Penyediaan Energi Listrik Di Desa Banaran, Yogyakarta (Skripsi). Yogyakarta: Universitas Muhammadiyah Yogyakarta.

Roger S. Pressman. (2002). Rekayasa Perangkat Lunak Pendekatan Praktisi (Buku Satu), ANDI. Yogyakarta. 
Saragih, Astriani R. (2016). Rancang Bangun Perangkat Pemberi Pakan Ikan Otomatis Pada Teknik Elektro Fakultas Teknik Universitas Maritim Raja Ali Haji Tanjung Pinang.

Setiawan, Iwan. Programmable Logic Controller (PLC) dan Teknik Perancangan Sistem Kontrol. (2006). Deli Publishing dan Andi : Yogyakarta

Ujianto, Cindi N.P.,dkk. (2010). Rancang Bangun Sistem Otomasi Pemberi Makan Ikan
Kolam Ikan Berbasis Arduino. Jurusan

Berbasis Mekanika dan Mikrokontroller. Teknik Telekomunikasi Fakultas Ilmu Terapan Universitas Telkom

Whitten, Jeffrey L, et al. (2004). Metode Desain \& Analisis Sistem, Edisi 6, Edisi International, Mc GrawHill, ANDI. Yogyakarta. 